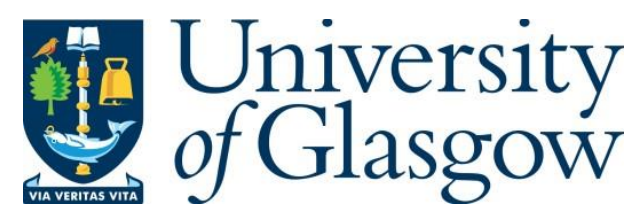

Kelliher, D. (2015) The 1984-5 miners' strike and the spirit of solidarity. Soundings: A Journal of Politics and Culture, 60(60), pp. 118-129.

There may be differences between this version and the published version. You are advised to consult the publisher's version if you wish to cite from it.

http://eprints.gla.ac.uk/155164/

Deposited on: 15 January 2018

Enlighten - Research publications by members of the University of Glasgow

http://eprints.gla.ac.uk 


\section{The 1984-5 miners' strike and the spirit of solidarity Diarmaid Kelliher}

\section{In spite of the defeat, the solidarity of $1984-5$ remains inspirational}

The thirtieth anniversary of the 1984-5 British miners' strike against pit closures has seen a number of attempts to engage with the legacy of the dispute. The prominence given to London Lesbians and Gays Support the Miners (LGSM), whose story had previously circulated among sections of the left but was hardly known more widely, has been perhaps the most unexpected (and welcome) outcome of this. In this article I discuss three depictions of the strike, all of which focus on miners, activists and supporters of the strike - and in all of which LGSM plays a role, though of varying importance. These works are then taken as a starting point for a wider discussion on the ways in which the miners' support movement is represented and understood.

The best known of the works discussed here is Pride, the film based on a dramatised account of LGSM and the group's relationship with mining communities in the Dulais Valley in South Wales. The second work discussed, the play Pits and Perverts, was written by Micheál Kerrigan and produced by Derry theatre group Sole Production; it focuses more closely on one gay couple living in London who provided accommodation for two striking Welsh miners. The third work is a documentary directed by Owen Gower, Still the Enemy Within, which attempts to give an overview of the strike primarily from the perspective of the rank-and-file activist - including secretary of LGSM Mike Jackson.

The focus on activists is a feature shared by all three works. Much mainstream commentary on the strike, at the time and since, has portrayed it as a dispute largely between the NUM's President Arthur Scargill, and Margaret Thatcher and Ian McGregor of the National Coal Board. All three figures were of course important, and no complete analysis of the dispute can ignore them. Nevertheless, the 180,000 miners, their families, communities and supporters deserve to be made central to any discussion of that year. Each of these works, in different ways, does this. Each also engages with themes that have relevance beyond the strike itself.

\section{The labour movement and the miners' support campaign}

After the strike began in March 1984, spreading unevenly from Yorkshire and Scotland into all the British coalfields, an extensive support movement was established. One of the most notable features of this was the women's support groups organised in the mining areas themselves, which formed the basis for the national Women Against Pit Closures (WAPC) campaign. Other support groups not limited to women also developed in the coalfields, such as the Neath, Dulais and Swansea Valleys Miners' Support Group, with which LGSM formed an alliance. Outside of mining areas there were support groups established both in Britain and internationally. Often these were geographically based - a group for a particular town, city or borough for instance - and trades councils were frequently at the heart of them. In addition there were more novel groups, such as LGSM, Black Delegation to the Miners and Greenham Women for a Miners Victory. Solidarity activity was not limited to these specific support groups however; Labour and Communist Party branches, local authorities, trade unions, student unions, community groups and any number of other 
campaigning organisations played a role in sustaining the miners for the year of the strike.

Still the Enemy Within in particular attempts to take in the whole range of this support movement, which was described by one miner as 'incredibly inspiring'. Unlike the other two pieces considered here, however, Still the Enemy Within also tries to analyse the failure of the strike, and roots this primarily in the limits of trade union solidarity. The interviews with miners and supporters here are a powerful reminder of how devastating the defeat of the strike was. More than one miner recalls how men committed suicide after the closure of their pits. This is important to keep in mind when discussing the positive connections that developed during the year. Still the Enemy Within recognises that the failure to get the majority of Nottinghamshire miners - the second largest mining area at the time - out on strike was a serious setback. As important however, the film suggests, was the limited nature of solidarity from other trade unionists. In particular, it is clear that, compared to the successful 1972 and 1974 miners' disputes, solidarity was expressed more through donations than sympathetic action. In the iconic moment of the 1972 strike, thousands of Birmingham engineering and car workers walked out and joined the miners picketing the Saltley coke depot. In 1984, when they were struggling to get support from unions and their members in power stations and in steel plants, the NUM pointed out that they were only asking for the same support they had received in the 1970s.

If the trade union support looked somewhat pale compared to the early 1970s, perhaps it looks more impressive from our vantage point. Transport workers and dockers did attempt to block the transport of coal and substitute fuels by rail and sea. Print workers on the Sun refused to print some of the worst coverage of the strike and the most vicious personal attacks on Arthur Scargill. This clearly was not enough, but Still the Enemy Within's explanation is only a partial answer. In some cases it is actually too generous. The documentary highlights the failure of the trade union leadership to back up their supportive words by calling on their members to take sympathetic action, but, for example, Eric Hammond of the electricians' union did not even rhetorically support the miners. In other unions attempts to get support from members for the strike failed. The local government union NALGO, for example, was made to stop donating nationally to the miners' support funds by a special conference forced by union members hostile to the strike. The TGWU could not prevent fuel blocked by its members from rail transport from being carried by road.

For those who supported the strike, the confidence of the early 1970s was missing. Large scale unemployment and de-industrialisation, legislation designed to undermine sympathetic action, and successive Conservative electoral victories all contributed. As Still the Enemy Within outlines, the Conservatives had deliberately planned a confrontation with the unions, and had strategies for negating aspects of their power. However, it is also necessary to acknowledge that many trade union members were ambivalent or opposed to the strike. If lessons are to be learned from the pattern of solidarity during this dispute, they should include accounting for the failure to gain support among significant numbers of trade union members.

Despite all this, there was significant and dedicated support for the miners and the mining communities. The strike was, as Mike Jackson explains in Still the Enemy Within, 'a beacon'. It brought together a diverse range of people who wanted to stand 
up to the attacks of Thatcherism. Much of this involved more longstanding elements of the trade union movement, but, as the case of LGSM shows, it was broader than this. In both Pride and Pits and Perverts it is made clear that there was an ability to identify with the struggle of the miners at least in part because of a sense of shared oppression. Lesbian and gay activists argued that they too faced hostility from the Thatcher government, the police and the media. The central character of Pits and Perverts roughly quotes Brendan Behan that 'there's no situation so dismal the police couldn't make it worse'. A similar argument was made by black supporters.

It is equally necessary to recognise, however, that the diverse groups that gave solidarity to the miners should not be seen as somehow existing outside of the labour movement. Pragna Patel, who was part of Black Delegation to the Miners, recently argued that 'the aim was very much to situate ourselves as part of a wider labour movement'; although the wider labour movement had 'often failed black workers', nevertheless, 'we felt that critique can be mounted whilst you're still situated within it'. ${ }^{1}$ A necessary context for understanding LGSM that is not offered in any of these accounts is the campaigning and self-organisation of lesbian and gay activists within the labour movement, especially from the mid-1970s. Support groups such as Black Delegation and LGSM were therefore part of an attempt to broaden the labour movement, not bypass it entirely.

\section{Solidarity and intersectionality}

Pride highlights the potential that relationships of solidarity have for changing attitudes. Some of those who were hesitant or hostile in Dulais towards LGSM are seen rethinking their position as a result of the personal contact and practical support. There are hints as well, though less developed, that those from Dulais undermined the notion of mining communities as irredeemably socially conservative. Largely missing, however, is the sense that LGSM was in part an attempt to change the London lesbian and gay scene. According to one activist it was about bringing both 'socialism onto the agenda of sexual politics in the London lesbian and gay community ... [and] sexual politics onto the agenda of trade union politics'. 2 Understandings of the support movement as 'cross-class', while not entirely inaccurate, can miss some of this dynamic. In Still the Enemy Within, Mike Jackson explains that the welcome and acceptance they received from Dulais was particularly important for him because he was from a working-class community himself. While working-class lesbians and gay men often moved to London, LGSM argued that the scene in the city was middle-class dominated. Bringing the miners' strike into prominent lesbian and gay spaces in the capital was in part about challenging this.

Pride, perhaps understandably, opts for a more straightforward story of solidarity between two different communities. One problematic simplification, however, is the way in which Lesbians Against Pit Closures (LAPC), which formed as a breakaway from LGSM, is largely played for laughs along classic leftist splintering lines. There is some suggestion of difficulties within the group, but it is left largely unexplored. Women were significantly outnumbered in LGSM, something that is obscured by how small the group as a whole appears in Pride. Some women involved in LGSM claimed that the behaviour of men in the group, including those trying to push a particular party agenda, was alienating. Perhaps just as significantly, some LAPC activists saw themselves as part of the women's movement around the strike, which included Women Against Pit Closures but also feminist groups outside the coalfields. 
'Lesbian and gay' unity was not a given, in particular when autonomous women's organising offered an alternative. One review of Pride suggested that the film was essentially 'a feelgood treatise on intersectionality', yet it focuses on the unity attained between what are conceived of as two distinct groups of people. ${ }^{3}$ The intersection of gender and sexuality, and that of class and sexuality, evident to some extent in Still the Enemy Within, is largely elided.

Pits and Perverts presents a more complex picture, making the class issues more explicit, and engaging with the politics of Northern Ireland. Pride touches briefly on the latter: Mark Ashton, the founder of LGSM, who was from Portrush, comments that, having grown up in Northern Ireland, he knows 'all about what happens when people don't talk to each other'. In Pits and Perverts the main character, Sean, is from the Bogside in Derry. After moving to London he still suffers nightmares about his friend who was killed by the British Army during Bloody Sunday. The connection made, then, is one of state oppression rather than people not speaking to each other. Early in the play, one of the South Wales miners worries that they are staying with 'with a fucking gay Irish terrorist'. The tension is intensified because some of the miners know people in the army serving in Ireland. 'There's not much work for lads like us in Wales. It's the pits or the army' comments one. Sean in particular makes a connection between 'working-class people killing each other' in Ireland, and the tragic case of the David Wilkie, the Welsh taxi driver who was killed by miners trying to stop strike-breakers in 1984 . Working-class unity is particularly difficult, the play suggests, when working-class people are made to fight on both sides.

During the strike there were attempts to make connections between the struggles in Northern Ireland and those of the miners. One striking Leicestershire miner, for instance, was taken by the Troops Out Movement to Belfast to meet Sinn Fein activists: 'It was awkward for me because my family was military - I'd got brothers in the army - but I thought I'd go over and see what it was all about'. He attended a march against internment on the Falls Road, which started out 'quite pleasant', but then suddenly there were 'rubber bullets and gas flying up the street'. If the solidarity campaign around the strike enabled these kind of experiences and new understandings to develop, conflicts did not of course disappear. A rally for the miners at the Greater London Council's County Hall, with representatives from Sinn Fein and the Palestinian Liberation Organisation, received hostile attention from some members of the GLC's Labour administration. The former Yorkshire miner, NUM-sponsored MP and Northern Ireland Secretary Roy Mason claimed he was 'horrified to learn of Ken Livingstone's latest episode' which was 'supposedly designed to help my union'.5 Support was not always welcome wherever it came from, and while Pits and Perverts and Pride in particular focus on the establishment of mutual understanding, not all antagonisms were resolvable.

\section{Longer trajectories of solidarity}

All three pieces give an impressive sense of the novelty of the relationships developed through the 1984-5 solidarity movement. A narrow focus on that year, however, risks missing some important context, including alliances developed in the 1970s.

Thus a student activist from 1984 featured in Still the Enemy Within describes feeling that the miners were probably wondering if they really needed students' help on picket lines, but then realising that student supporters had gained respect through their 
activity. Yorkshire miner Joe Henry is seen stating his belief that industrial workers tended to look down on students, although he personally admired them. Speaking at York University to raise funds had been 'a big personal moment' for him, because he discovered he could talk as an equal.

These kinds of encounters, however, had been prefigured on a smaller scale in the disputes of the early 1970s. Kent miner Malcolm Pitt described pickets being put up by London students in 1972: 'Student solidarity often put the miners into a totally unknown environment, and home-loving conservatives found themselves in the completely unconventional atmosphere of a student commune.' As he noted, the student hospitality had created a permanent relationship between Goldsmiths College and Tilmanstone Colliery, and the LSE and Snowdown Colliery. ${ }^{6}$ Arthur Scargill similarly described a 'fantastic display of solidarity' when a thousand Yorkshire miners were put up by Essex University students during the same dispute, during which they 'showed to the university students a degree of discipline and organization which they had probably read about in their Marxist books, but had not seen for themselves'.

While it is important to recognise what was new in 1984-5, and how personally revelatory many of these experiences could be for individuals, there is a risk of missing the way in which solidarity in part relied on longer histories of activism. Still the Enemy Within emphasises how new much of the experience was for the women from the coalfields. And in Pits and Perverts we see a Welsh miner worried because his wife is joining a picket line. He comments: 'Mary has gone all political. She joined the South Wales Women's Support Group. I had to make my own tea.' While it is true that for many these experience were new, it is important to recognise that not all women who were active in 1984-5 had been previously apolitical. And it is not necessary to go back to 1926 for this; for example, Kent miners' wives had been involved picketing in 1972. Interviews with women active in miners' support groups in North East England during 1984-5 suggest that some of them were already political or community activists before the strike, and there were family traditions of women's activism in mining and the broader labour movement. ${ }^{8}$ Some, of course, were trade unionists themselves. Betty Heathfield, for example, who played a prominent role in the national Women Against Pit Closures organisation, had long been a member of the Communist Party. Others were active in the Labour Party: the women's support group in Chesterfield seems to have developed out of a Women's Action Group established to campaign for Tony Benn in the 1984 by-election. While the strike brought many new people into political activity, support groups often benefited from the impetus of those who were already politically engaged.

More generally, focusing on 1984-5 risks positioning mining areas as only ever being recipients of solidarity. Still the Enemy Within does look further back: Paul Symonds from Frickley Colliery describes the enduring importance in the mines of the 'whole idea of solidarity and sticking together'. Indeed this sense of a tradition of solidarity within the coalfields is crucial in understanding how the strike lasted for so long.

Yet there was also a history of miners and their communities supporting others in struggle, something that is too often obscured by portrayals of insular mining communities. Jack Taylor, the President of the Yorkshire NUM in 1984-5, told the Union of Communication Workers conference: 'We deserve your support. We've 
never turned us backs on anybody in our union, never'. ${ }^{9}$ This long tradition included, for example, Communist Party-influenced internationalism of the early twentieth century in South Wales and Scotland in particular, which saw miners among those who joined the International Brigades in 1930s Spain. In the late 1970s, the large numbers of miners who joined the picket lines supporting the Grunwick strikers were a notable feature of the dispute. This strike in a photo-processing company in the London Borough of Brent, which mainly involved South Asian women, is often considered an important moment in the history of labour movement support for blackled industrial action. Miners from South Wales, Yorkshire, Scotland and Kent - the 'left' areas of the NUM - joined picket lines in London in significant numbers. One miner estimated that there were 1300 miners from just Yorkshire joining a mass picket at Grunwick in July 1977, another recalled that they did not have enough bus spaces for the numbers that wanted to go. ${ }^{10}$ This kind of history, of which Grunwick is just one example, is important, because it helps frame the support in 1984-5 as part of an ongoing reciprocal relationship of solidarity. The 1984-5 miners' support group in Brent pointed to relationships developed when they supported the miners in 1972 and 1974, and continued when the miners support the Grunwick and Trico strikes in the borough in the late 1970s.

Much of this mutual support was encapsulated in the phrase 'the labour movement', which Raymond Williams described as the "coming together, under hard conditions, to help each other, to connect immediate struggles, to move through and beyond them to change society'. ${ }^{11}$ Grunwick is of particular interest here, however, because it pointed to the more diverse alliances that would be seen during the 1984-5 strike. A recent interview with a Yorkshire miner who was seventeen when he joined the Grunwick picket line encapsulates this well:

I'd never seen anything like it. There were students, women demonstrators shouting ... an actual gay group, who we got talking to. A group of guys standing there who were obviously gay standing in unity with the sacked workers. I'd never met people like that. There were good feelings there. There were working-class people regardless of race, age, colour. ${ }^{12}$

Mining activists were not only involved in supporting industrial disputes. The sense of internationalism continued in campaigning against apartheid, with South Wales miners, for instance, protesting against the South African rugby union team playing in Cardiff in 1970. Arthur Scargill supported the formation of the Anti-Nazi League (ANL) in the late 1970s, and spoke from the platform of the second ANL carnival in 1978, with four coachloads of Yorkshire miners among the trade unionists in attendance. In 1979 a Miners Against Nazis conference in Sheffield, organised by Yorkshire NUM and the ANL, was attended by two hundred delegates from the coalfields. All this is not to idealise the politics of the miners. Clearly it was a minority that were politically active - which Still the Enemy Within suggests was still the case in 1984-5 - and there was significant variation between and within different mining areas. Yet this history of diverse solidarity from the miners helps position the support movement in a more expansive context, and it encourages us to think about the way mining communities in some instances actively sought diverse support, rather than having it forced reluctantly upon them. 
If looking back is important for thinking about solidarity and the miners' strike, so is looking beyond that year. Pride and Pits and Perverts both point to the way in which mining communities and their union supported lesbian and gay rights as a direct result of the solidarity they had received from LGSM. This included voting for gay rights motions at Labour and TUC conferences, a delegation joining the 1985 London Lesbian and Gay Pride demonstration, and national NUM and local coalfield campaigning against the homophobic Section 28 of the 1988 Local Government Act. Still the Enemy Within does look further forward, briefly taking in the financialisation of the economy, the campaign against further pit closures under the Major government in the early 1990s, and the 2008 crash, and suggests that recent antiausterity campaigning is a continuation of the same struggle that the miners and their supporters waged.

A recent documentary about Women Against Pit Closures, Going Through the Change, makes more explicit the way in which the experience of the miners' strike was a resource upon which others could draw. Although released recently, the film focuses mostly on a WAPC re-union event in 2004. From this it branches out to look at a number of struggles, successful and unsuccessful, including long disputes at Hillingdon hospital in the 1980s and on the Liverpool docks in the 1990s, during which WAPC activists provided inspiration and practical support. Speaking at a screening of the documentary at the Bishopsgate Institute in London, one WAPC member said that many were now actively involved in Unite the Union's Community section. While some members of WAPC dropped out of activity after the defeat of the miners, others continued to campaign and share what they had learned.

\section{Conclusion}

It is important not to gloss over the significance of the defeat of the miners' strike. Still the Enemy Within argues that the defeat was a hugely important moment in the consolidation of the neoliberal agenda. A key part of this agenda was the weakening of the labour movement, and it is hard to argue that it has not been largely successful. Critical thinking about the 1984-5 miners' solidarity movement has a crucial role to play in understanding this success. Despite the committed support of large numbers of people, there was also many within the labour movement, most obviously the Nottinghamshire miners, who were not convinced by the case made by the strikers and their union.

Yet if romanticism is to be rejected, so is an excessive defeatism. As some of the debate around the Kilburn Manifesto has suggested, the neoliberal project seeks to establish that there is no other way. These revivals of the spirit of solidarity of 1984-5 help to keep alive the memory and possibility of alternatives. Pits and Perverts explicitly contrasts the famous Thatcherite notion that 'there is no community' with the bonds of solidarity developed by large numbers of people. Pride may smooth some of the edges, and avoid delving into the labyrinthine party politics of the 1980s British left, but it brings to a wide audience the idea that the labour movement is not just a sectional concern. In the film Dai Donovan tells Mark Ashton about a miners' lodge banner with two hands grasped:

that's what the labour movement means, should mean. You support me, I support you, whoever you are, wherever you come from, shoulder to shoulder, hand to hand. 
The story of LGSM in particular suggests the possibility for solidarity that recognises diversity: that uniting does not mean subsuming difference or ignoring the problems of our movements. If the labour movement has frequently failed to live up to such ambitions, the fact that Pride can gain popularity while representing such aspirations is all the more to be welcomed.

Notes

1. Pragna Patel interviewed by Rachel Cohen for 'Sisterhood and After: The Women's Liberation Oral History Project', 2011. Available at the British Library.

2. All Out! Dancing in Dulais, 1986: www.coolcave.co.uk/blog/video/all-out-dancingin-dulais-1986.html.

3. Ben Walters, 'Pride', Sight and Sound, October 2014: www.bfi.org.uk/newsopinion/sight-sound-magazine/reviews-recommendations/film-week-pride.

4. David Bell, The Dirty Thirty: Heroes of the Miners' Strike, Five Leaves 2009, p94.

5. 'Red Ken accused of being "wet nurse to terror"', Daily Mail, 5.12.84; 'IRA and PLO Pledge to Miners', East Anglia Daily Times, 8.12.84.

6. Malcolm Pitt, The World on Our Backs: The Kent Miners and the 1972 Miners' Strike, Lawrence and Wishart 1977, p177.

7. Arthur Scargill, 'The New Unionism', New Left Review 92, July-August 1975, p12. 8. Jean Spence and Carol Stephenson, 'Female Involvement in the Miners' Strike 1984-1985: Trajectories of Activism', Sociological Research Online 12:1, January 2007: www.socresonline.org.uk/12/1/Spence.html.

9. Union of Communication Workers, In Support of the Miners, 1984:

www2.warwick.ac.uk/services/library/mrc/explorefurther/filmvideo/miners/.

10. These interviews are from two separate documentaries on a DVD produced by Brent Trades Council in 2007, The Grunwick Strike 1976-8. There is a copy of the DVD at the Brent Archives.

11. Raymond Williams, Resources of Hope: Culture, Democracy, Socialism, Verso 1989, p248.

12. Andy Beckett, When The Lights Went Out: Britain in the Seventies, Faber 2009, p403. 